Hall, R. P. \& Hughes, D. J. 1982: Transitional amphibolite-granulite facies granites, diorites and metavolcanic amphibolites in the Isukasia map sheet, southern West Greenland. Rapp. Grønlands geol. Unders. 110, 46-49.

McGregor, V. R. 1973: The early Precambrian gneisses of the Godthåb district, West Greenland. Phil. Trans. R. Soc. Lond. A 273, 343-358.

Nakamura, N. 1974: Determination of REE, Ba, Fe, Mg, $\mathrm{Na}$ and $\mathrm{K}$ in carbonaceous and ordinary chondrites. Geochim. cosmochim. Acta 38, 757-775.

Nielsen, B. L. 1976: Economic minerals. In Escher, A. \& Watt, W. S. (edit.) Geology of Greenland, 460 487. Copenhagen: Geol. Surv. Greenland.

Secher, K. 1983: Noritic rocks and associated nickel-copper-sulphide occurrences in Sukkertoppen district, central West Greenland. Rapp. Grønlands geol. Unders. 115, 30-34.

Tarney, J. \& Windley, B. F. 1977: Chemistry, thermal gradients and evolution of the lower continental crust. J. geol. Soc. Lond. 134, 153-172.

Wells, P. R. A. 1979: Chemical and thermal evolution of Archaean sialic crust, southern West Greenland. J. Petrol. 20, 187-226.

Department of Geology,
Portsmouth Polytechnic,
Burnaby Road,
Portsmouth POI $3 Q L$,
U.K.

\title{
Field work between Fiskefjord and Godthåbsfjord, southern West Greenland
}

\begin{abstract}
Adam A. Garde
Introduction

The 1980-1981 field work in Precambrian basement rocks for the Fiskefjord map sheet was continued in 1983 . V. R. McGregor mapped granulite facies gneisses south of outer Fiskefjord in the south-western part of the map sheet area. The author worked inland between Godthåbsfjord and Fiskefjord from the eastern map sheet boundary at $50^{\circ} 54^{\prime} \mathrm{E}$ westwards to $51^{\circ} 45^{\prime} \mathrm{E}$ (fig. 22) and some notes concerning the lithologies, geometry and geochronology of this area are presented below.

The GGU cutter $K . J$. V. Steenstrup and a Jet Ranger helicopter on weekly charter from Godthåb provided logistic support for the two Fiskefjord teams and for four teams mapping in the Ivisârtoq area (see Brewer et al., this report) as well as for the GGU glaciological station at Qamanârssûp sermia.
\end{abstract}

\section{Lithologies and field relations}

The area mapped by the author (fig. 22) is underlain by uniform and homogeneous orthogneisses, equivalent to the Nûk gneisses of the Godthåbsfjord region, in which there 


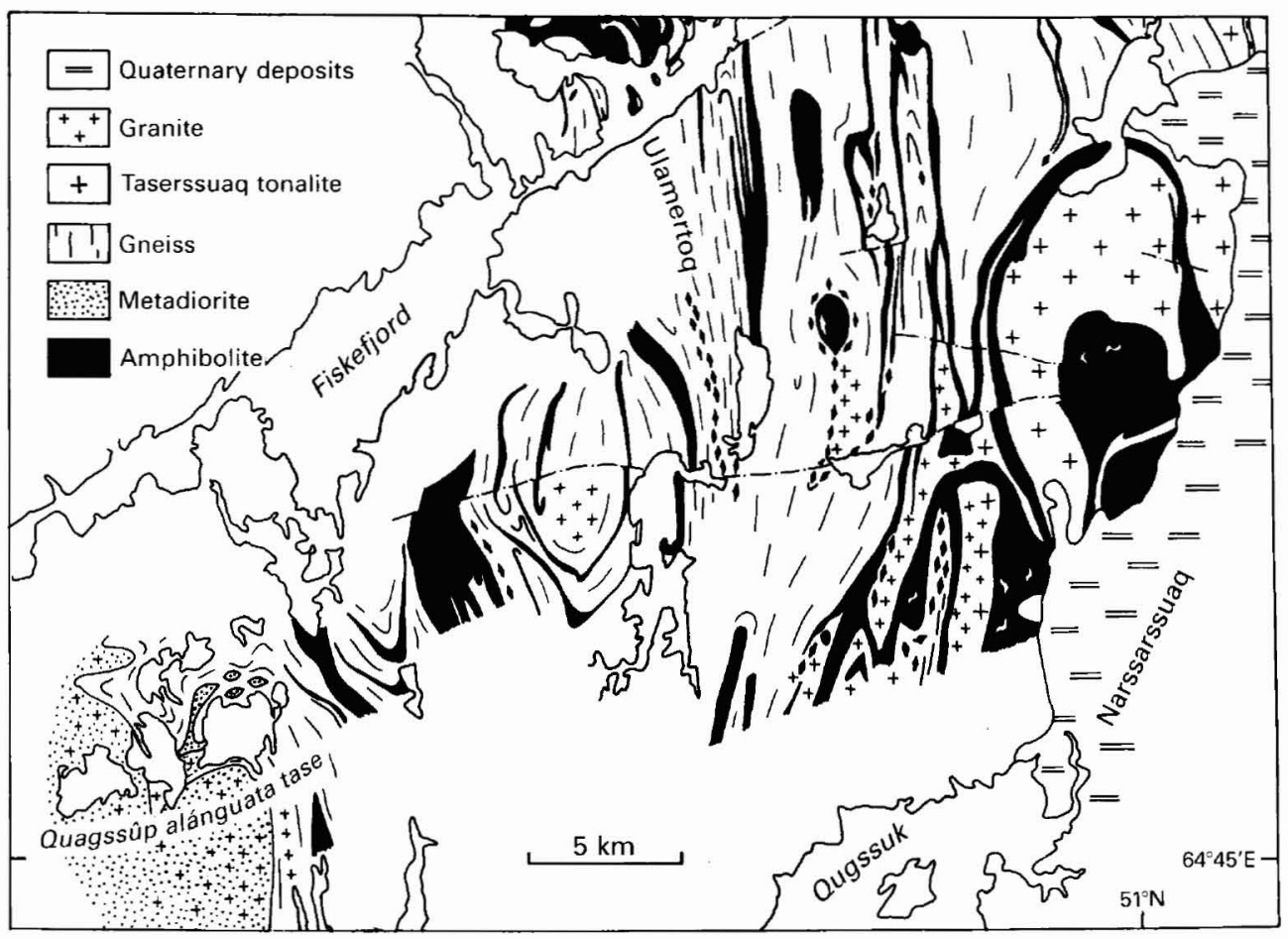

Fig. 22. Simplified geological map of the north-eastern part of the Fiskefjord map sheet area, mapped in 1981 and 1983.

are numerous older amphibolite horizons, frequently accompanied by ultramafic lenses and containing a few very thin but persistent units of variegated metasediments, equivalent to Malene rocks. An extensive, not previously recognised unit of mainly dioritic composition predates the bulk of the gneisses. The later Taserssuaq tonalite, which occupies the central and southern parts of the Isukasia map sheet area (Garde et al., 1983), extends southwards to Qugssuk in the eastern part of the area. It is succeeded by a leucocratic granitic rock in the area immediately north of Qugssuk.

\section{Supracrustal rocks and metadiorite}

The amphibolites and equivalent two-pyroxene bearing pyribolites form massive horizons up to a kilometre thick as well as much thinner bands and trains of inclusions in the leucocratic rocks. There are two main groups, both of which are older than the gneisses where mutual relations can be established. The first group, a continuation of the amphibolites in the western part of the Isukasia map sheet area, is characterised by variable grain size, common compositional banding, and the occasional presence of diopside-brown garnet-calcic plagioclase (-calcite) skarn lenses. The amphibolites sometimes grade laterally into grey intermediate plagioclase-hornblende-biotite (-quartz) rocks with distinct compositional banding on a millimetre to centimetre scale. These 'grey amphibolites' may extend for 
Fig. 23. Metadiorite enclaves (1) in gneiss (2), both cut by several phases of granite and pegmatite (3-6).



more than a kilometre within or along ordinary amphibolite horizons. Both types are believed to be of extrusive volcanic origin. The banded amphibolites are commonly also intercalated with homogeneous, medium-grained mafic amphibolites of presumed intrusive origin, and contain bodies of mainly dunitic ultramafic rocks.

In three areas within the amphibolites very thin but persistent horizons of metasedimentary rocks were seen. They are concordant to banding and foliation of the amphibolites, and intrusive sheets of gneiss into the amphibolites also cross-cut the metasediments. In several localities the metasediments have mutual contacts with ultramafic rocks associated with the amphibolites. The metasediments are predominantly layers a few metres thick of light brown garnet-biotite gneiss, alternating with even thinner rusty schistose bands containing additional cordierite and sillimanite, boudinaged fine-grained whitish quartzite, as well as grey to grey-brown biotite-hornblende (-pyroxene) gneiss that may be of volcanic origin.

The amphibolite horizons with their associated ultramafic and metasedimentary rocks essentially all link up to retain a continuous, although now structurally complex framework of mafic crust, into which the precursors of the gneisses were intruded.

The second group of amphibolite forms discrete horizons north-west of the head of Qugssuk and further westwards. It has a uniform grain size of $c .1 \mathrm{~mm}$ and is homogeneous and non-banded, and less mafic than most of the amphibolites described above. No metasediments have been observed associated with these horizons which are believed to be of intrusive origin and probably disrupted members of the metadiorite complex described next. 


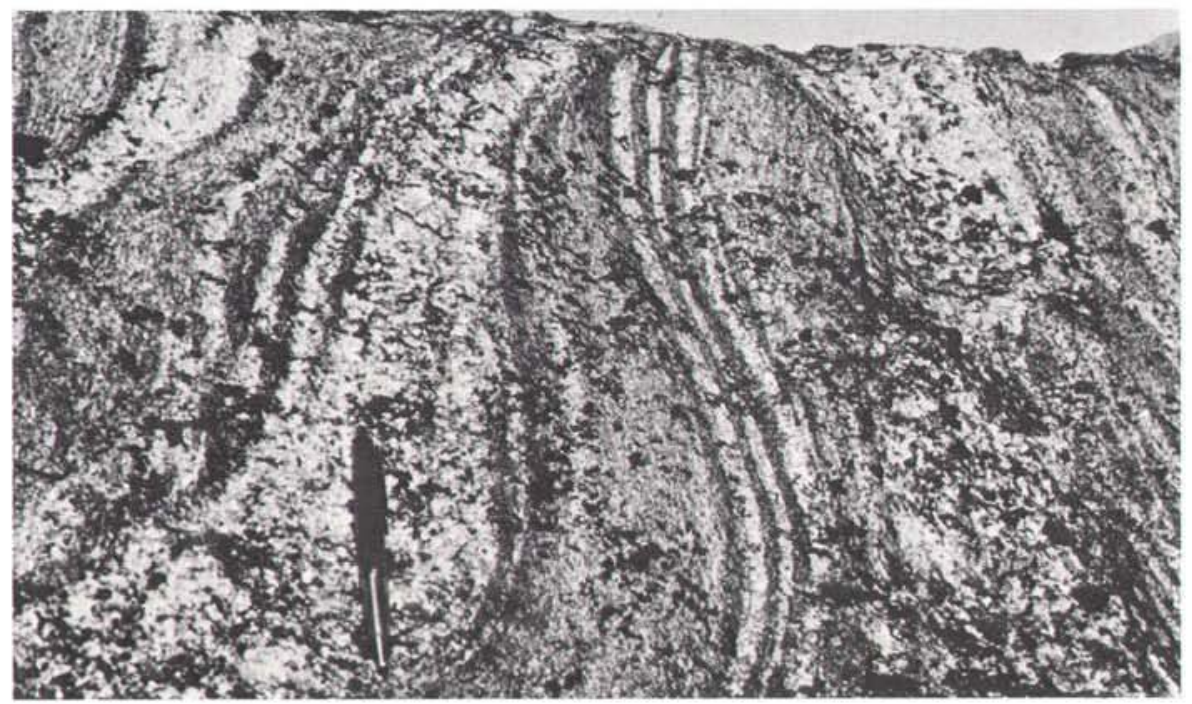

Fig. 24. Field relations between Taserssuaq tonalite (grey) and younger granite sheets (white). The contacts are characterised by mafic border zones in the tonalite that probably formed during partial anatexis.

Around the three lakes Quagssûp alánguata tase and west of the ground mapped by Lauerma (1964), an extensive area of uniform metadiorite was encountered, which contrasts with the intermediate to acid gneisses with their horizons of supracrustal amphibolite. The rock is fine grained and rather homogeneous, foliation is weak or absent, and it is further characterised by slight variations in mafic mineral content, as shown by dark nebulitic mafic patches on a scale of centimetres. A crude hexagonal pattern of early quartz-plagioclase veinlets is common and indicates a general low degree of deformation in the homogeneous rock. The metadiorite grades into a more mafic amphibolitic rock, especially towards its north-eastern border, outside which the isolated homogeneous amphibolites described above occur. The metadiorite complex extends southwards into central Nordlandet outside the mapped area (see discussion).

The metadiorite is split up by tonalitic to granodioritic gneisses at its mapped northern and eastern boundaries (fig. 23) and is extensively intruded on a scale of metres by still younger granitic rock and associated pegmatite. This may form as much as half the outcrop in the eastern part of the complex. Discrete granitic sheets also intrude the gneisses in the vicinity of the metadiorite complex. No age relations could be established between the metadiorite and supracrustal amphibolites. It is suggested that the former formed in the interval between the deposition of the amphibolites and intrusion of the main gneisses.

\section{Leucocratic rocks}

The predominant tonalitic to granodioritic gneisses in the area mapped in 1983 resemble those described to the north (Garde \& McGregor, 1982; Garde et al., 1983). Only minor 
areas of hypersthene gneisses, all partially retrogressed, were encountered in 1983, and textural evidence of retrogression is not very widespread in the opinion of the author. In the granitic rocks that swamp the metadiorite complex and intrude the adjacent gneisses, no definite field evidence was found of former granulite facies metamorphism.

The easternmost part of the map sheet area bounding Narssarssuaq is occupied by homogeneous, medium- to coarse-grained rocks of granodioritic to tonalitic composition, which belong to the Taserssuaq tonalite (Garde et al., 1983). North of Qugssuk it is split from the tonalitic gneisses to its west by an up to $2 \mathrm{~km}$ wide north-south trending zone dominated by white to pinkish, medium- to coarse-grained, leucocratic granites. The proportion of granitic sheets in the gneiss gradually increases from the west, and their mutual contacts are generally sharp. Towards the east, however, the transition between the granite and the Taserssuaq tonalite is different. It is often diffuse on an outcrop scale, but locally with textural evidence that the granite has been sweated out of the Taserssuaq pluton by partial anatexis (fig. 24).

\section{Structure}

The area mapped in 1983 is characterised by a transition from the general steep northsouth trending attitudes of isoclinally folded amphibolite markers in the north-eastern corner of the map sheet to a more open north-south structure with several domes outlined by amphibolites, separated by areas with steep foliation. The domes seem to have been formed during the rise of the youngest leucocratic intrusions, notably the Taserssuaq tonalite and associated granite in the east. Mapping of the dome structure west of Ulamertoq, which contains little deformed leucocratic gneiss in its centre, is not completed. Domal structures are also characteristic of other parts of the Fiskefjord area (Berthelsen, 1960; Lauerma, 1964). In the area north of Quagssûp alánguata tase recumbent tight folds have been refolded by a large synform structure with a south plunging axis.

The mapped area is situated between the two prominent north-east trending Ataneq and Fiskefjord faults (Garde et al., 1983; Brewer et al., this report). It contains conjugate sets of minor ENE- and ESE-trending faults, but their lateral displacement seldom exceeds a few tens of metres.

\section{Discussion}

An interesting result of the field work in 1983 is the observation that the central part of the area between Fiskefjord and Godthåbsfjord contains a large metadiorite pluton which predates the bulk of the gneisses. Similar rocks have been seen in the southern, granulite facies part of the map sheet area (V. R. McGregor, personal communication) but were not separated from the gneisses. The metadiorite complex with the late granitic intrusives may be continuous with the Akia granulites invaded by Kua granulites (Macdonald, 1974) and the diorite gneisses with Imartuneq granite (sensu lato) (Reed, 1980) from Nordlandet. However, a correlation through the lichen-covered granulite facies rocks of Nordlandet is not easily carried out, and the rock divisions by Macdonald (1974) and Reed (1980) could not be extended throughout Nordlandet where mapping is completed (McGregor, 1:100 000 geological map 64 V.1 S, in press). Considerable amounts of dioritic rocks have also been found during recent mapping by R. P. Hall and D. J. Hughes for the Isukasia map sheet

4 Rapport 120 
(Hall, this report). Their diorite complex closely resembles the metadiorites mapped by the author with respect to relative age, lithology, and their setting in complicated folded amphibolite facies terrain containing supracrustal amphibolites.

The presence of dioritic rocks in the area between Fiskefjord and Godthåbsfjord was thought to be related to depletion of mobile elements during the granulite facies metamorphic event; alternatively the dioritic rocks could have been intruded into a deeper crustal level than is exposed further north, as indicated by the simpler structure, apparent rarity of supracrustal rocks and extensive granulite facies assemblages to the south (V. R. McGregor, personal communication; Reed, 1980). The point is made here that the dioritic rocks in Nordlandet need not be related to an unusually deep crustal level and granulite facies metamorphism in that area. They are now known to be separate from and older than the main gneisses and not the result of a transition of the latter into granulite facies terrain. Very similar rocks occur within amphibolite facies terrain in the neighbouring Isuaksia map sheet area, intruding supracrustal amphibolites.

\section{References}

Berthelsen, A. 1960: Structural studies in the pre-Cambrian of western Greenland II. Geology of Tovqussap nunâ. Bull. Grønlands geol. Unders. 25 (also Meddr Grønland 123,1), 223 pp.

Garde, A. A., Hall, R. P., Hughes, D. J., Jensen, S. B., Nutman, A. P. \& Stecher, O. 1983: Mapping of the Isukasia sheet, southern West Greenland. Rapp. Gronlands geol. Unders. 115, 20-29.

Garde, A. A. \& McGregor, V. R. 1982: Mapping in the Fiskefjord area, southern West Greenland. Rapp. Grønlands geol. Unders. 110, 55-57.

Lauerma, R. 1964: On the structure and petrography of the Ipernat dome, western Greenland. Bull. Grønlands geol. Unders. 46 (also Bull. Comm. géol. Finlande 251), 88 pp.

Macdonald, R. 1974: Investigations on the granulites of southern Nordland, Godthåbsfjord, central West Greenland. Rapp. Grønlands geol. Unders. 65, 44-49.

McGregor, V. R. (comp.) in press: Geological map of Greenland 1:100 000, Qôrqut, 64 V.1 S. Copenhagen: Geol. Surv. Greenland.

Reed, S. J. 1980: The petrology of high grade Archaean rocks from Nordlandet southern West Greenland. Unpubl. Ph. D. Thesis, Univ. Exeter. 